\title{
Reflections on the Status of Filipino Philosophy ${ }^{1}$
}

\section{Leonardo N. Mercado}

\begin{abstract}
This short essay contains some of my musings concerning the present status of Filipino philosophy. These reflections may be divided into three parts. First, on the existence of Filipino Philosophy. Second, my reactions to the evaluation of F.P.A. Demeterio III on Filipino philosophers. Third, a proposal for the future undertakings of philosophical institutions in our country.
\end{abstract}

Keywords: Demeterio, Filipino philosophy, indigenous thought, culture

I

n 1974, after I came out with my first book, Elements of Filipino Philosophy, the work was met with skepticism. The reaction is understandable because the majority of our academe were still hooked to the Western intellectual and cultural dominance. But, in his preface to my book, The Filipino Mind, which came out in 1994, George F. McLean, the secretary of the Council for Research in Values \& Philosophy, wrote:

Leonardo Mercado was one of the first to appreciate the philosophical significance of this evolution. When he wrote his first book on the subject the World Congresses of Philosophy were being devoted regularly to philosophy and science (Varna 1973, and Dusseldorf 1978); it was not until the Montreal Congress in 1983 and after a long struggle that culture was recognized as a philosophical theme, and indeed became a locus for philosophical investigation. ${ }^{2}$

\footnotetext{
${ }^{1}$ A report delivered to the Philippine Academy of Philosophical Research (PAPR) on 7 December 2014.

2 George F. McLean, Preface to Leonardo N. Mercado, The Filipino Mind: Philippine Philosophical Studies II (Washington DC and Manila: Logos Publications, Inc., 1994), ix.

(c) 2016 Leonardo N. Mercado

http://www.kritike.org/journal/issue 19/mercado december2016.pdf

ISSN 1908-7330

(c) BY-NC-ND
} 


\section{THE STATUS OF FILIPINO PHILOSOPHY}

The offering of Filipino philosophy in our universities, colleges, and seminaries has slowly grown. And, it fermented the interest of students and teachers.

\section{The Report of F.P.A. Demeterio III}

Thirty years after I came out with my first book, F.P.A. Demeterio III of De La Salle University evaluated the status of Filipino Philosophy. ${ }^{3} \mathrm{He}$ examined the "status and directions for Filipino Philosophy" in the writings of seven philosophers, namely: Fernando Zialcita, Florentino Timbreza, Emerita Quito, Romualdo Abulad, Napoleon Mabaquiao, Rolando Gripaldo, and Alfredo Co. Demeterio concludes:

Hence, in having rendered obsolete the question "Is there a Filipino philosophy?," Filipino students and younger scholars of philosophy could select which among the twelve highly developmentally useful forms of Filipino philosophy they want to work on. By doing so, their consequent philosophical researches would hopefully contribute to the further enrichment of Filipino philosophy until the question, "Is there a Filipino philosophy?" fades away from the Philippine historical horizon. ${ }^{4}$

However, Demeterio excludes me in his study for the following reason:

Leonardo Mercado (1975), who without a doubt is one of the pioneers of Filipino philosophy, is not included in this comparative study because he tended to insist on a singular form of Filipino philosophy, which is the cultural, anthropological, or ethnophilosophical discourse. Unlike Mercado, many of the pioneering Filipino philosophers discussed the myriad forms of the mode of existence of Filipino philosophy. ${ }^{5}$

\footnotetext{
${ }^{3}$ F.P.A. Demeterio III, "Status and Directions for 'Filipino Philosophy' in Zialcita,

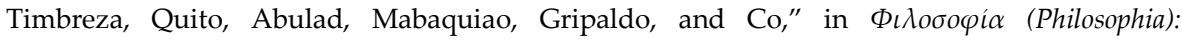
International Journal of Philosophy, 14:2 (2013), 213.

${ }^{4}$ Ibid., 212.

${ }^{5}$ Ibid., 313.

(c) 2016 Leonardo N. Mercado http://www.kritike.org/journal/issue 19/mercado december2016.pdf ISSN 1908-7330 
In Table 1 of his article, Demeterio comes out with sixteen forms of Filipino philosophy according to their strengths, weaknesses and overall assessments: (1) grassroots/folk philosophy; (2) lecture on scholasticism/Thomism; (3) lecture on other foreign systems; (4) critical philosophy as non-academic discourse; (5) application of logical analysis; (6) application of phenomenology/existentialism/hermeneutics; (7) critical philosophy as an academic method; (8) appropriation of foreign theories; (9) appropriation of folk philosophy; (10) philosophizing with the use of the Filipino language; (11) textual exposition of foreign systems; (12) revisionist writing; (13) interpretation of Filipino worldview; (14) research on Filipino values and ethics; (15) identification of the presuppositions and implications of the Filipino worldview; and (16) study on the Filipino philosophical luminaries. ${ }^{6}$

The classification of Demeterio shows that the philosophers mentioned still have not totally cut off their apron strings from the Western masters. He writes:

To conclude, this paper has shown that out of the sixteen forms of Filipino philosophy, one should no longer be referred to as a philosophical discourse, namely, folk/grassroots philosophy; two have low developmental usefulness, namely, the lectures on Scholasticism/Thomism and the lectures on other foreign theories; one has a medium developmental usefulness, namely, (1) critical philosophy as nonacademic discourse; (2) application of logical analysis; (3) phenomenology/existentialism/hermeneutics as an academic method; (4) critical philosophy as an academic method; (5) appropriation of foreign theories; (6) appropriation of folk philosophy; (7) philosophizing with the use of the Filipino language; (8) revisionist writing; (9) interpretation of Filipino worldview; (10) research on Filipino values and ethics; (11) identification of the presuppositions and implications of the Filipino worldview; and (12) study on the Filipino philosophical luminaries. Concerning no. 9 on the appropriation of folk philosophy (as represented by Timbreza, Quito, Mabaquiao, and Gripaldo), the author praises its "highly developmental usefulness due to use of Filipino concepts and system of thinking." Concerning no. 4

${ }^{6}$ Ibid., 212.

(c) 2016 Leonardo N. Mercado http://www.kritike.org/journal/issue 19/mercado december2016.pdf ISSN 1908-7330 


\section{THE STATUS OF FILIPINO PHILOSOPHY}

(interpretation of Filipino worldview by Zialcita, Quito, Timbreza, Co, Abulad, Mabaquiao, and Gripaldo), the author proposes the said interpretation as a guide to Filipino academicians. ${ }^{7}$

After one year, Demeterio came out with a follow-up study. It is entitled "Assessing the Developmental Potentials of Some Twelve Discourses of Filipino Philosophy," The study evaluates the writings of 26 individuals based on the academic institutions from the entire country. Demeterio classifies them according to the following categories of Filipino philosophy:

1. The exposition of foreign systems,

2. The application of logical analysis,

3. The application of phenomenology and hermeneutics,

4. The appropriation of foreign theories,

5. As revisionist writing,

6. As academic critical analysis,

7. As the interpretation of Filipino worldview,

8. As research of Filipino ethics and values,

9. As the appropriation of folk spirit,

10. As the study on the presuppositions and implication of the Filipino worldview,

11. As the study of the Filipino philosophical luminaries, and,

12. Philosophy in the Filipino language. ${ }^{8}$

\section{My Reactions to the Report of Demeterio}

What do I think of the categories of Demeterio? The following is my understanding of Filipino philosophy. It will be in the areas of "the interpretation of Filipino worldview," "the interpretation of ethics and values," as well as "philosophy as reflected in Filipino language/s."

We assume there is a modal Filipino, meaning the majority which is pictured in a bell-curve with extremes spread to the left and to the right. The representatives will range from the indigenous groups who live on the mountains or in the seas like the Badjaos to the sophisticated dwellers of the exclusive places in Metro Manila. The majority in the center depicts the modal Filipino.

${ }^{7}$ Ibid., 312.

8 F.P.A Demeterio III, "Assessing the Developmental Potentials of Some Twelve Discourses of Filipino Philosophy", Philippiniana Sacra, 49:147 (May-August 2014).

(C) 2016 Leonardo N. Mercado

http://www.kritike.org/journal/issue 19/mercado december2016.pdf

ISSN 1908-7330

(c) BY-NC-ND 
Every people has a world view, which is how a people views reality from their perspective. It is like viewing outside the window from the inside. Now if the view is from the outside to the inside, that is culture. Luzbetak defines culture as "a dynamic system of socially acquired and socially shared ideas according to which an interacting group of human beings is to adapt itself to its physical, social, and ideational environment." 9 The philosophy of a people is how they view and judge reality from their perspective, that is, from the inside. We assume that Filipino identity is both dynamic and static. As dynamic, it is like saying that the English of Shakespeare is English, which is partly the same and partly different from modern English.

A part of culture is the ideational, which includes concepts and values; this is the area of philosophy. Now somebody will object: "If there is no written philosophy or text, then that group of people has no philosophy." The objection may be applied to language. If there is no written grammar, then there is no language. But, the members of the tribe perfectly speak their language even if there is no written grammar. The grammar has to be observed and written down by a language scholar. Australian national television reported that the language of a group of Australian aborigines is about to vanish because their few members are dying out. So, a Caucasian anthropologist spent his time with them, learned their language, and wrote down its grammar. When applied to worldview and philosophy, here is the example of the unwritten grammar becoming written.

Demeterio says that one area of Filipino philosophy is the study of Filipino philosophical luminaries. For example, to study the writings of Jose Rizal may yield insights on Filipino philosophy. We must remember that each person embodies three levels: the universal, on one extreme, and the particular or individual, on the other extreme, and the national in the middle. In Shakespeare's The Merchant of Venice, the Jewish money-lender, Shylock explains that he as a Jew has emotions like the rest of humankind. The other extreme is the individual. The Philippine national hero, Jose Rizal, as an individual has his unique traits. For example, his height which has been computed as four feet and eleven inches (as based on his clothes in Fort Santiago) or even as low as $4^{\prime} 6^{\prime \prime}$ according to one eye-witness. Has his short height affected his character and also his philosophy? (The same question may also be applied to Napoleon Bonaparte who was quite short). The Filipino in Rizal is what he has inherited from his family and acquaintances. He also embodied the knowledge and philosophies he has gained from his Western education and travels.

\footnotetext{
9 Louis J. Luzbetak, The Church and Cultures: New Perspectives in Missiological Anthropology (New York: Orbis Books, 1988), 19.
}

(c) 2016 Leonardo N. Mercado http://www.kritike.org/journal/issue 19/mercado december2016.pdf ISSN 1908-7330 


\section{THE STATUS OF FILIPINO PHILOSOPHY}

Another example is Immanuel Kant. Does he represent German philosophy? A Prussian or northern German with the strong sense of duty, his doctrine of categorical imperative does certainly reflect north German culture and values. Or how has French culture influenced Blaise Pascal and Henri-Louis Bergson?

The Western stress on the individual has influenced the Western emphasis on human rights, like the right to private property, liberty, and pursuit of individual happiness.

In short, if Filipino philosophy is the making explicit of the Filipino world view and philosophy as reflected in their culture, then there are different methodologies for achieving that. I have used several. One is through linguistic methodologies, such as the phenomenology of behavior and comparative oriental philosophy.

\section{A Proposal}

If a people's philosophy consists in making explicit their world view, allow me to make a proposal. Let us begin with an example. In social philosophy, Western thought values the individual in preference to the social. For example, the law has two sides: duties and rights. This theme on human rights has occupied the modern Western thought from Hobbes onwards. Let us summarize here what we have treated elsewhere. ${ }^{10}$ Although the following brief summary may do injustice to this wide field, at least I want to point out a broad panorama in the light of the individual and the social.

Thomas Hobbes (1588-1679) theorizes that primitive humans were anti-social. There was no state then. Hobbes postulated that the transition to being social was through the establishment of the Social Contract. For the sake of achieving peace, the early humans decided to renounce voluntarily their individual liberties and give it to an absolute ruler. The state operates through the rule of law which assures individual freedom and protects private property.

John Locke (1632-1704) modified Hobbes' theory of social contract. Locke modified it by not making absolute the power of the ruler, that people have the right to revolt against a tyrant ruler, that the government has checks and balances, that there should be separation of church and state.

In France, Charles-Louis de Secondat (1689-1755), better known as Baron de Montesquieu, added sociological factors to the concept of law. He said that the law must consider the climate of the country, its political and

\footnotetext{
${ }^{10}$ Leonardo N. Mercado, Political and Legal Philosophies: Western, Eastern, and Filipino (Manila: Logos Publications, 2008).

(c) 2016 Leonardo N. Mercado http://www.kritike.org/journal/issue 19/mercado december2016.pdf ISSN 1908-7330
}

(cc) BY-NC-ND 
economic conditions, the temperament of the people, their customs and traditions. In short, the law must factor in the people's culture.

Jean-Jacques Rousseau (1712-1778) taught that sovereignty resides in the people and thereby inspired the French Revolution. Through the Social Contract, the people became intelligent in running their own affairs. Since the power of the law comes from the people, the law must also have popular backing.

Immanuel Kant (1724-1804) also stressed the individual. His theory of self-legislation is the heart of his practical philosophy. The self-legislation is "Act so that the maxim can always at the same time hold good as a principle of universal legislation." The law is to obeyed for its own sake (again, selflegislation). Laws for him are framed in his individualistic philosophy.

The individualism of John Stuart Mill (1806-1873) stresses the individualistic pursuit of happiness insofar as such a pursuit does not infringe on the rights of others. Hence, the first form of government is one which insures the most liberty for its citizens.

Although the list of Western thinkers is not exhaustive, we can see the drift, that is, how Western thought in general has this individualistic direction. We cannot, however, be simplistic because there are others who may also think otherwise.

The point I am driving at is this: If Western philosophers are products of their culture and world view, we see that their philosophies somehow complement each other. They are variations of the same theme and individualism.

My proposal is the following: that the philosophical institutions encourage various Filipino philosophers to write on a common theme. If various Western philosophers through the ages wrote on the individual and human rights and individual freedom and therefore enriched the topic, something can be done if Filipino scholars write on the Filipino as a social being, on human duties and their implications. Another possible area is on the philosophy of becoming (in contrast to being). Our Oriental mind is like the Chinese principle of yin and the yang. There may be other themes.

In this postmodern age, we may thus show the rest of the world the riches of Filipino thought.

Department of Philosophy, University of Santo Tomas, Philippines

\section{References}

Demeterio, F.P.A. III, "Assessing the Developmental Potentials of Some Twelve Discourses of Filipino Philosophy," in Philippiniana Sacra, 49:147 (2014).

(c) 2016 Leonardo N. Mercado

http://www.kritike.org/journal/issue 19/mercado december2016.pdf

ISSN 1908-7330

(cc) BY-NC-ND 


\section{THE STATUS OF FILIPINO PHILOSOPHY}

, "Status and Directions for 'Filipino Philosophy' in Zialcita, Timbreza, Quito, Abulad, Mabaquiao, Gripaldo, and Co," in

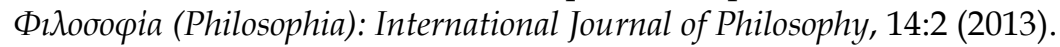

Luzbetak, Louis J., The Church and Cultures: New Perspectives in Missiological Anthropology (New York: Orbis Books, 1988).

McLean, George F., Preface to Leonardo N. Mercado, The Filipino Mind: Philippine Philosophical Studies II (Washington D.C. and Manila: Logos Publications, Inc., 1994), ix.

Mercado, Leonardo N., Political and Legal Philosophies: Western, Eastern, and Filipino (Manila: Logos Publications, 2008).

(c) 2016 Leonardo N. Mercado

http://www.kritike.org/journal/issue 19/mercado december2016.pdf

ISSN 1908-7330

(cc) BY-NC-ND 